\title{
Reduction technology of carbon dioxide emission from a coal utilized power generation system
}

\author{
H. Makino \& N. Noda \\ Central Research Institute of Electric Power Industry, Japan
}

\begin{abstract}
Coal is an important energy resource for meeting the further demand for electricity, as coal reserves are much more abundant than those of other fossil fuels. But, coal utilization technology produces carbon dioxide more than other fossil fuels, because of the higher carbon content of coal. For the control of the global warming problem, it is required to develop a new technology for the reduction of carbon dioxide emission from coal-utilized power stations.

To reduce carbon dioxide emission, it is very important to develop a new technology of high efficiency power generation system and utilize biomass energy of carbon neutral. For the further reduction of carbon dioxide, the removal and storage technology is an effective one. It is necessary to apply the smart process of powder technology for the development of coal utilized power generation system of new type including a high efficiency power generation system and carbon dioxide removal type power generation system. For the utilization of biomass energy, it is very important to develop the smart technology for the handling of biomass like drying, carbonizing, pulverizing and conversion technology.

In this paper, many technologies for the powder handling related to the high efficiency coal utilized power generation, biomass utilization and carbon dioxide removal power generation are introduced. Furthermore, the present level of these technologies and the development tendency for the future are surveyed.

Keywords: coal utilization, carbon dioxide, biomass, low rank coal, high efficiency power generation.
\end{abstract}




\section{Introduction}

Coal is an important energy resource for meeting the further demand for electricity, as coal reserves are much more abundant than those of other fossil fuels. But, coal utilization technology produces carbon dioxide more than other fossil fuels, because of the higher carbon content of coal. For the control of the global warming problem, it is required to develop a new technology for the reduction of carbon dioxide emission from coal-utilized power stations.

To reduce carbon dioxide emission, it is very important to develop new technology of a high efficiency power generation system and utilize low carbonized coal or biomass energy of carbon neutral. Furthermore, carbon dioxide removal technology is one figure but it requires large power consumption and high cost.

In this paper, the utilization technology of low rank coal which is low carbon content, and the biomass utilization technology for the pulverized coal combustion are investigated at first. And, the development situation of the Integrated Coal Gasification Combined Cycle and Integrated Coal Gasification Fuel Cell Combined Cycle as a high efficiency power generation system is introduced. Finally, some methods of carbon dioxide removal technology and fuel upgrading technology are overviewed.

\section{Utilization technology of sub-bituminous coal}

As the low carbonized coal like sub-bituminous coal or lignite is lower carbon concentration than bituminous coal, the utilization of low carbonized coal has the possibility to reduce $\mathrm{CO}_{2}$ emission. Especially, the minable reserve of subbituminous coal is over $30 \%$ of that of bituminous coal, so the utilization of subbituminous coal in pulverized coal combustion is investigated in Japan. But, the property of sub-bituminous coal is different from that of bituminous coal. For the reduction of $\mathrm{CO}_{2}$ emission by using sub-bituminous coal, it is important to maintain the same power generation efficiency with bituminous coal. In this chapter, the new combustion technology for pulverized sub-bituminous coal is investigated in pulverized coal combustion test furnace in CRIEPI. The outline of this test furnace is indicated in Figure 1.

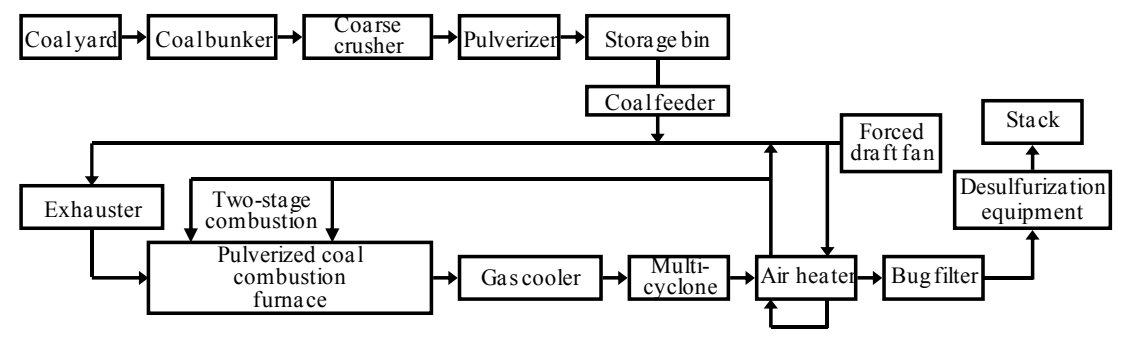

Figure 1: $\quad$ Outline of the coal combustion test facility. 


\subsection{Combustion technology of sub-bituminous coal}

Figure 2 indicates the difference of the oxygen distribution in test furnace [1]. Fig. 2 (a) shows the distribution on bituminous coal combustion and Fig. 2 (b) shows that on sub-bituminous coal combustion. Oxygen consumption in furnace is affected by combustion situation, so this contour indicates the shape of combustion flame. The oxygen consumption rate near the burner exit on subbituminous coal combustion is lower than that on bituminous coal combustion, because the evaporation period of the moisture in sub-bituminous coal is necessary before combustion. So, the ignition of sub-bituminous coal is later compared with bituminous coal. And, after the ignition the flame on subbituminous coal combustion is diffused rapidly to the outer side of the furnace. This phenomenon is caused by the diffusion of pulverized coal particle. As subbituminous coal includes high concentration moisture, the coal particle of subbituminous coal becomes porous or bursts to fine particles by the rapid evaporation of moisture in the pore. Small coal particles or porous coal particles have weak inertia, so these particles are easy to be diffused by swirl force of combustion air.

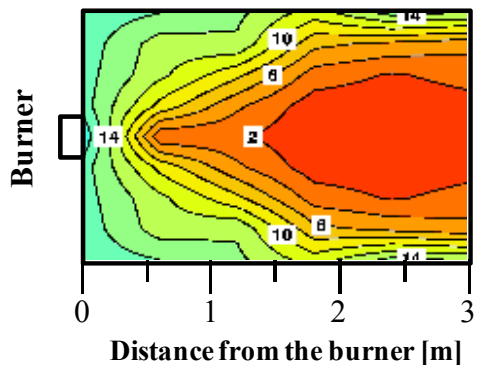

(a) Bituminous coal

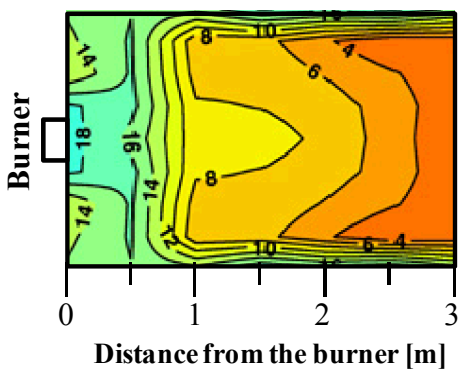

(b) Sub-bituminous coal

Figure 2: Difference of the oxygen distribution in test furnace.

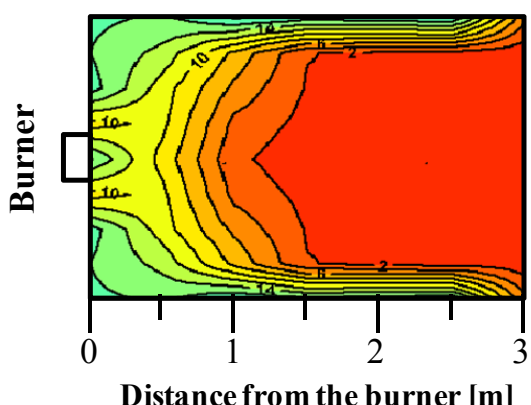

Figure 3: Oxygen concentration by modification on sub-bituminous coal.

As the solution method of this problem, the reduction of the flow rate of primary air and reduction of the swirl force of secondary air is effective. The reduction of primary air velocity can improve the ignition point closer to burner 
exit and the reduction of swirl force can reduce the diffusion of coal particle to the outer side of the furnace. Figure 3 indicates the oxygen concentration of the flame controlled by this modification on sub-bituminous coal combustion [1]. The flame shape of this condition is similar to the flame shape on bituminous coal combustion shown in Fig. 2 (a). In this condition, NOx and unburned carbon concentration in fly ash can be reduced same level with bituminous coal combustion and flame temperature distribution becomes similar of bituminous coal combustion, so the power generation efficiency is seemed to be same level with bituminous coal combustion.

\subsection{Blend combustion of sub-bituminous coal with bituminous coal}

In utility boiler, the coal whose property is different from usual coal is utilized by blend combustion with other kind coal. In this section, the blend combustion characteristics of sub-bituminous coal with bituminous coal are investigated.

Figure 4 indicates the NOx concentration and conversion to NOx of fuel bond nitrogen on blend combustion [2]. NOx concentration and conversion to NOx of fuel bond nitrogen on blend combustion become mean value of those of each coal combustion. Figure 5 indicates the unburned carbon concentration in fly ash and unburned fraction on blend combustion [2]. The unburned carbon concentration on blend combustion is higher than the mean value of those of each coal combustion. And, unburned carbon fraction on blend combustion has the maximum value at the condition of blend ratio of $25 \%$ sub-bituminous coal and $75 \%$ bituminous coal. This tendency is caused by the influence of moisture in sub-bituminous coal on bituminous coal combustion. The combustible in subbituminous coal is better than bituminous coal, so the unburned carbon fraction becomes low in sub-bituminous coal combustion. On the other hand, as the combustion characteristics of combustible in bituminous coal is worse than that of bituminous coal, the unburned carbon fraction of bituminous coal on blend combustion with sub-bituminous coal becomes higher by the influence of the moisture in sub-bituminous coal. To prevent this problem, it is effective to divide the injection burner for sub-bituminous coal and bituminous coal.

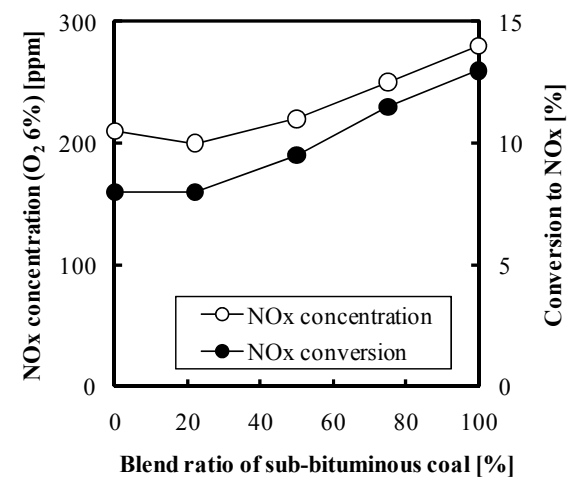

Figure 4: NOx concentration and conversion on blend combustion. 


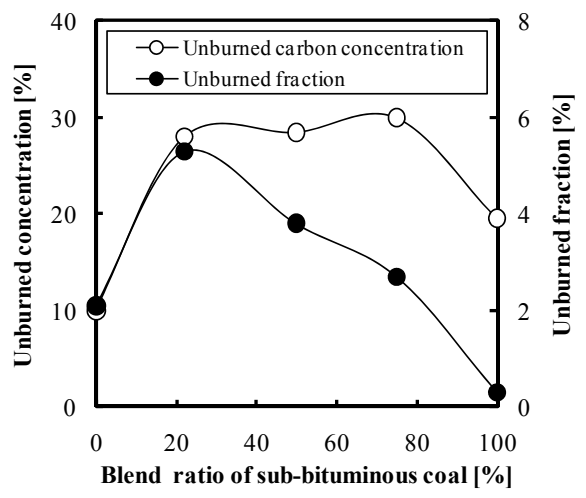

Figure 5: Unburned carbon concentration in fly ash and unburned fraction on blend combustion.

\section{Utilization of biomass energy}

Biomass is defined as carbon neutral energy because biomass is renewable. But, as there are many kinds of biomass species including woodchip, wood pellet, sewage sludge, and so on, the pulverizing characteristics and combustion characteristics of these species are different each other. At now, the usual method for the utilization of the biomass energy is blend combustion in pulverized coal combustion boiler. In CRIEPI, many kinds of biomass species are investigated on blend combustion with pulverized coal in test furnace.

Figure 6 indicates the conversion to NOx in pulverized coal combustion and blend combustion of dried sewage sludge with pulverized coal (Newlands coal) [3]. The conversion to NOx on blend combustion of dried sewage sludge with pulverized coal is lower than that of pulverized coal combustion. The dried sewage sludge includes higher volatile matter compared to Newlands coal and the fuel ratio is lower, so the formation of NOx in the flame is controlled by the effective formation of reduction flame. Figure 7 shows the unburned carbon concentration in fly ash in pulverized coal combustion and blend combustion of dried sewage sludge and pulverized coal (Newlands coal) [3]. As the fuel ratio of dried sewage sludge is lower than Newlands coal and the ash content of dried sewage is high, it is considered that the unburned carbon concentration on blend combustion becomes lower than that on Newlands coal combustion.

Although the biomass utilization in pulverized coal combustion boiler is effective method for $\mathrm{CO}_{2}$ reduction, biomass worsens the pulverizing characteristics. So, it is necessary to develop the high performance pulverizing technology for biomass or mixture of coal and biomass. Furthermore, the potential usable volume of biomass is very low compared to the existed thermal power plant. So, it has to be noticed that the reduction effect of $\mathrm{CO}_{2}$ emission by biomass utilization is not so much for the emission of $\mathrm{CO}_{2}$ from thermal power plant. 


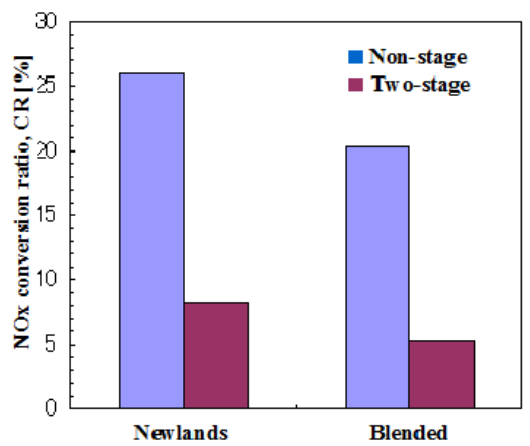

Figure 6: Unburned carbon concentration in fly ash and unburned fraction on blend combustion.

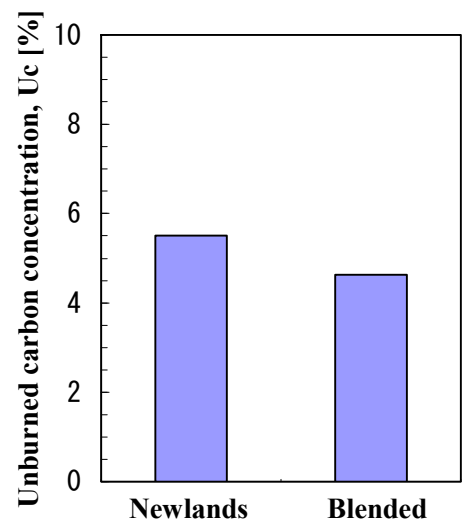

Figure 7: Unburned carbon concentration in fly ash in pulverized coal combustion and blend combustion of dried sewage sludge and pulverized coal.

\section{Development of high efficiency power generation system}

The high efficiency power generation system can reduce the $\mathrm{CO}_{2}$ emission for the required electric power. In Japan, the ultra super critical (USC) boiler has been operated and the steam condition is improved step by step. On the other hand, for the great improvement of power generation efficiency, the development of the integrated coal gasification combined cycle (IGCC) and the integrated coal gasification and fuel cell combined cycle (IGFC) are promoted.

Figure 8 indicates the system flow of IGCC process. In Japan, the demonstration plant of IGCC has been operated since 2007. This plant is succeeded for continuous run of 5,000 hours. But, this plant uses a wet gas 
cleaning system. For the more improvement of power generation efficiency, the development of hot gas cleaning system and utilization of high temperature gas turbine are important. In hot gas cleaning system, the development of the high performance adsorption material for $\mathrm{H}_{2} \mathrm{~S}, \mathrm{HCl}, \mathrm{HF}$ and so on is required. And, the functional material for thermal barrier coating is required for the development of high temperature gas turbine. In the future, the improvement of the reliability and cost performance is required.

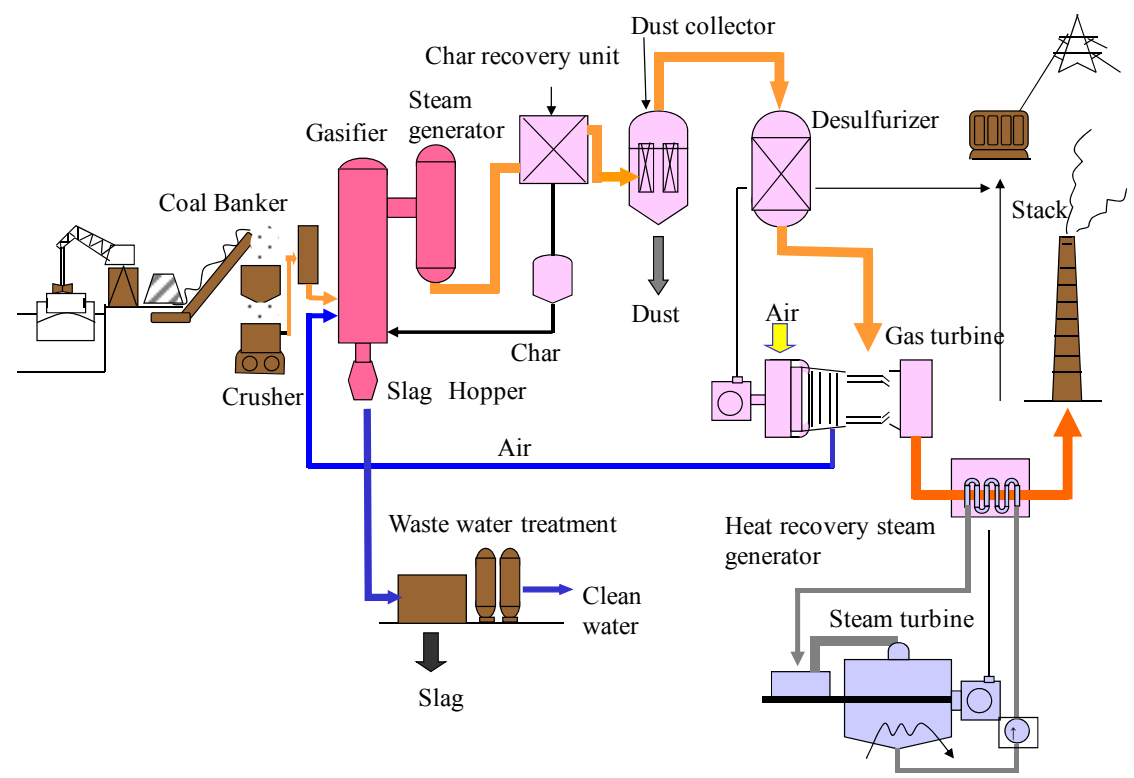

Figure 8: $\quad$ System flow of IGCC process.

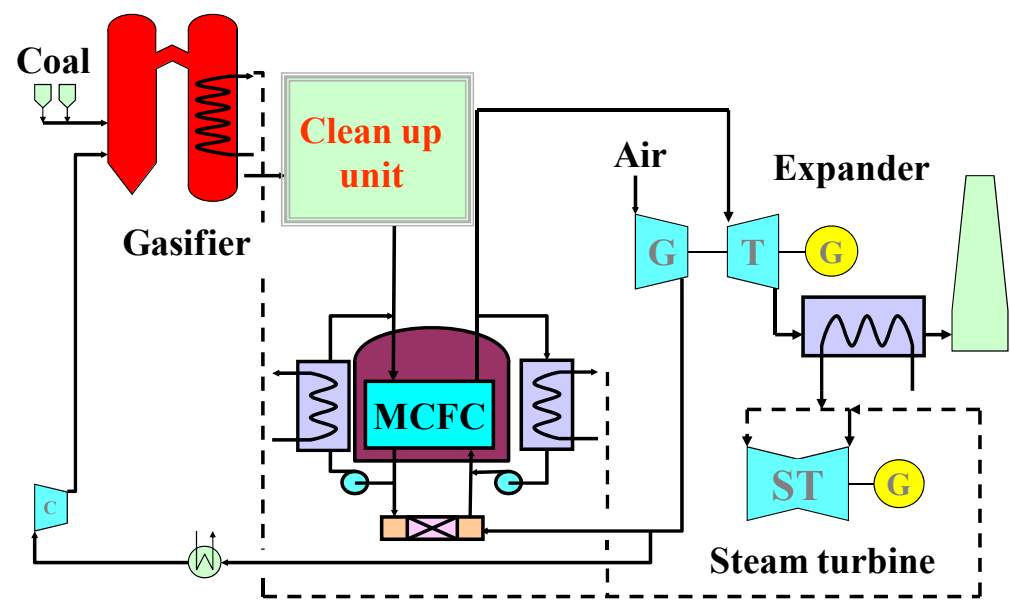

Figure 9: $\quad$ System flow of IGFC using MCFC. 
The high temperature fuel cell can maintain high efficiency of power generation. IGFC can be reduced $\mathrm{CO}_{2}$ emission more than IGCC. As a high temperature fuel cell, the molten carbonate fuel cell (MCFC) and the solid oxide fuel cell (SOFC) are investigated. Figure 9 shows the system flow of IGFC using MCFC. The main subjects of the utilization of MCFC are the improvement of the durability of the cell performance for long time and the cost performance. The cost of MCFC can be reduced about half and the cell performance can be kept over $90 \%$ of the initial performance after 40,000 hours' continuous run by the research using new smart material in CRIEPI.

\section{Investigation of $\mathrm{CO}_{2}$ capture and storage method}

To reduce $\mathrm{CO}_{2}$ emission greatly, the $\mathrm{CO}_{2}$ capture and storage (CCS) system is one method. But, $\mathrm{CO}_{2}$ emission from the thermal power plant is large amount, so $\mathrm{CO}_{2}$ removal method requires the reduction of power generation efficiency and the increase of power generation cost extremely. Figure 10 indicates the comparison of estimation result of power generation efficiency with and without $\mathrm{CO}_{2}$ removal. In general, the power generation efficiency of the thermal power plant with $\mathrm{CO}_{2}$ removal is about $30 \%$ lower compared to that of the power generation plant without $\mathrm{CO}_{2}$ removal. In these $\mathrm{CO}_{2}$ removal systems, the $\mathrm{CO}_{2}$ removal technology from IGCC system is better than the $\mathrm{CO}_{2}$ removal technology from the pulverized coal combustion power plant. For more improvement of power generation efficiency of IGCC system with $\mathrm{CO}_{2}$ removal, the development of high performance $\mathrm{CO}_{2}$ separation technology including the absorption process, the adsorption process, membrane separation process and so on. It seems that $\mathrm{CO}_{2}$ removal technology can be improved by the application of new smart material.

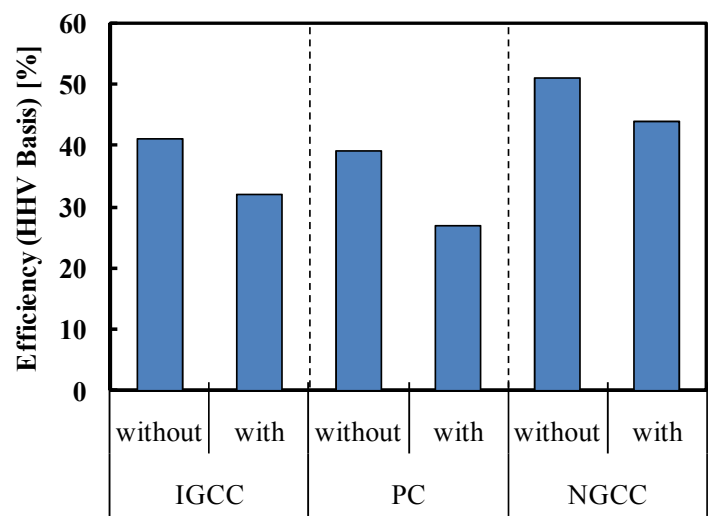

Figure 10: Comparison of estimation result of power generation efficiency with and without $\mathrm{CO}_{2}$ removal.

In CRIEPI, to keep the high efficiency power generation of IGCC when $\mathrm{CO}_{2}$ is removed, new type $\mathrm{CO}_{2}$ removal IGCC system using $\mathrm{O}_{2}-\mathrm{CO}_{2}$ blown gasifier 
and $\mathrm{O}_{2}-\mathrm{CO}_{2}$ blown gas turbine. Figure 11 shows the flow of this system [4]. This system is supposed a combination of IGCC and OxyFuel $\left(\mathrm{O}_{2}-\mathrm{CO}_{2}\right.$ blown $)$ pulverized coal combustion system. So, in this system, gasifier and gas turbine are operated $\mathrm{O}_{2}$ from the air separation unit and $\mathrm{CO}_{2}$ from recycled flue gas. As $\mathrm{CO}_{2}$ has gasification effect different from $\mathrm{N}_{2}$ and the performance of $\mathrm{CO}_{2}$ in gas turbine is higher than $\mathrm{N}_{2}$, the power generation efficiency of this system becomes higher than the other system. The development of this system is progressed in bench scale plant level.

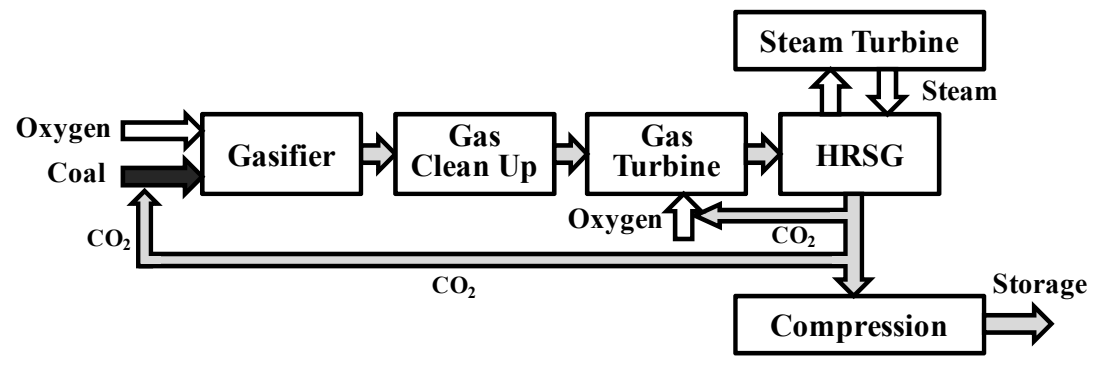

Figure 11: System flow of IGCC with $\mathrm{CO}_{2}$ removal.

\section{Upgrading of low rank coal and biomass}

In chapter 2 and 3, the utilization technology of the low rank coal and biomass is introduced. For the utilization of the low rank coal and biomass, the big problem is the included moisture. Although many kinds of upgrading technology of low rank coal and biomass are developed, the drying technology is one of most important methods. But the moisture in low rank coal and biomass is not only bulk moisture but also moisture in the pore, so it is difficult to remove the moisture efficiently. For the high performance of moisture removal, the methods using evaporation are effective. On the other hand, these methods require the higher power consumption for the increase of coal temperature.

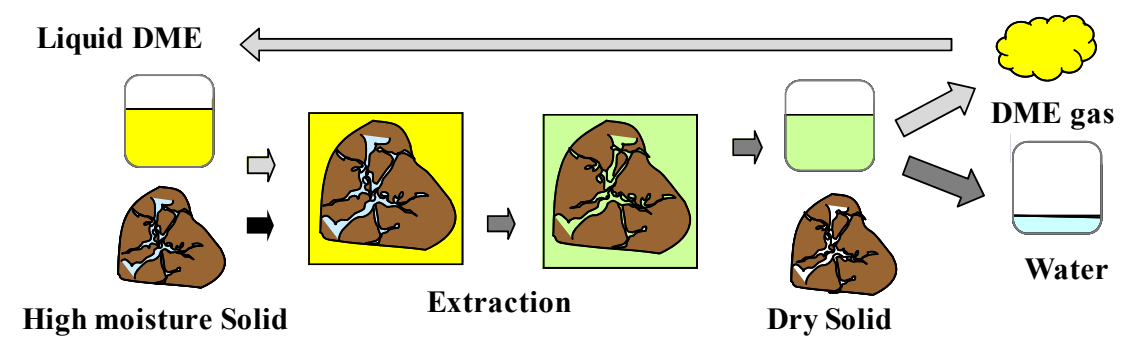

Figure 12: Concept of the extraction method using DME.

In CRIEPI, the extraction method using DME (di-methyl-ether) is investigated. Figure 12 shows the concept of this method [5]. DME is gas phase in ambient pressure and temperature, but it becomes liquid phase by 
pressurization in ambient temperature. And the liquefied DME can include moisture. So, in this system, the liquefied DME is mixed with the low rank coal or biomass, and DME extracts moisture. After the separation of liquefied DME including moisture with dried coal or biomass, DME converted to gas phase by decompression. And gaseous DME is separated with liquid water. The gaseous DME can be converted to liquid phase by pressurization, and DME is used again by recycling. This method can reduce the power consumption required for the drying of low rank coal and biomass.

\section{Conclusion}

Coal is an important energy resource for meeting the further demand for electricity, as coal reserves are much more abundant than those of other fossil fuels. For the coal utilization in the future, it is necessary to reduce $\mathrm{CO}_{2}$ emission. To reduce the $\mathrm{CO}_{2}$ emission, it is very important to develop new technology of high efficiency power generation system and utilize low carbonized coal and biomass energy of carbon neutral. For the further reduction of $\mathrm{CO}_{2}$ emission, the $\mathrm{CO}_{2}$ removal technology is effective one, but it requires high power consumption and cost.

It is necessary to apply the smart technology for new function material design and powder handing technology for the development of new type coal utilized power generation system including high efficiency power generation system and carbon dioxide removal power generation system. For the utilization of low rank coal and biomass energy, it is very important to develop the smart technology for the handling of low rank coal and biomass like drying, pulverizing and combustion. We'll continue to develop these technologies.

\section{References}

[1] Ikeda M., H. Makino, Y. Kozai, Emission Characteristics of NOx and Unburned Carbon in Fly Ash of Sub-bituminous Coal Combustion. JSME International Journal, Series B, 15, 3, pp506-511, 2002

[2] Ikeda M., H. Makino, H. Morinaga, K. Higashiyama, Y. Kozai, Emission Characteristics of NOx and Unburned Carbon in Fly Ash during Combustion of Blends of Bituminous/Sub-bituminous Coal Combustion. Fuel, 82, 13, pp1851-1857, 2003

[3] Tsuji H., H. Makino, H. Shirai, N. Ikemoto, K. Murai, S. Momoda, Blended Combustion of Dried Sludge Pellet with Pulverized Coal. Journal of the Japan Institute of Energy, 85, 9, pp769-772, 2006

[4] Oki Y., J. Inumaru, S. Hara, M. Kobayashi, H. Watanabe, S. Umemoto, H. Makino, Development of oxy-fuel IGCC system with $\mathrm{CO}_{2}$ recirculation for $\mathrm{CO}_{2}$ capture. Proc. of the $10^{\text {th }}$ Int. Conf. On Greenhouse Gas Control Technology, 2010

[5] Kanda H., H. Makino, M. Miyahara, Energy-Saving Drying Technology for Porous Media using Liquefied DME Gas. Adsorption, 14, 2, 2008 